\title{
MEMINIMALKAN KESALAHAN KONSEP PECAHAN MELALUI PEMBELAJARAN PENEMUAN TERBIMBING DENGAN GESTURE PRODUKTIF PADA SISWA SMP
}

\author{
Anton Prayitno', Dewi Tri Wulandari ${ }^{2}$ \\ ${ }^{1,2}$ Program Studi Pendidikan Matematika, Universitas Wisnuwardhana Malang \\ lantonpray.86@gmail.com
}

\begin{abstract}
Not easy to bring the students are able to understand the concept and meaning of fractions so we need a change in the way teaching is done by teachers because of possible knowledge is still limited so that the teacher always used the same way of time. In anticipation of this problem it is necessary to look for a formula appropriate learning so as to improve the ability to solve mathematical problems, especially in fractions. Teachers should continue to develop and implement a variety of ways variance so that students interested and excited in participating in math class one through guided discovery methods. From the above data shows that mistakes students in concepts and problem solving $13 \%$, this means that the mistakes made by the students at the time of surgery to learn fractions and solving problems can be minimized by guided discovery learning. Guided discovery learning, which is examined in this study is to present the information by observing the shape of object manipulation, making conjectures, explain, and evaluate
\end{abstract}

Keywords: guided discovery learning, gesture, fractions

\section{PENDAHULUAN}

Konsep pecahan dan operasinya merupakan konsep yang sangat penting untuk dikuasai sebagai bekal untuk mempelajari bahan matematika berikutnya. Pecahan merupakan salah satu materi penting penting dalam kurikulum sekolah dasar, namun pemahaman pecahan dan belajar bagaimana mengoperasikannya dapat menjadi masalah bagi anak-anak dan orang dewasa (Behr, Harel, Post, \& Lesh 1992 ; Mack 1990). Sucipto (2009) mengungkapkan pada di lapangan menunjukkan bahwa siswa di Sekolah Dasar (SD) mengalami kesulitan memahami pecahan dan operasinya, dan banyak guru menyatakan mengalami kesulitan untuk mengajarkan pecahan. Para guru cenderung menggunakan cara yang prosedural, yaitu memberikan aturan secara langsung untuk dihafal, diingat, dan diterapkan. Perubahan cara mengajar tidak banyak dilakukan oleh para guru karena mungkin pengetahuan yang masih terbatas sehingga mereka selalu menggunakan cara yang sama dari waktu ke waktu.

Muhsetyo (2007) menjelaskan bahwa pembelajaran pecahan memerlukan perhatian, kesungguhan, keseriusan, ketekunan, dan kemampuan profesional. Mengingat secara alami tingkat berpikir yang dominan dapat meniadakan kesulitan para siswa. Edward (2009) menjelaskan bahwa gesture adalah salah satu modalitas dimana orang mengekspresikan apa yang mereka pikirkan dan membangun pemahaman siswa tentang konsep-konsep matematika. Gesture sering dilakukan sebagai bukti bahwa tubuh terlibat dalam berpikir dan berbicara tentang ide-ide yang diekspresikan dalam gerakan. Artinya, gesture yang dilakukan merupakan bukti bahwa pengetahuan matematika dalam hal ini adalah pecahan yang dapat diwujutkan ke dalam bentuk konkrit, maka pembelajaran pecahan 
dapat menggunakan dan memanfaatkan benda-benda manipulatif di sekitar kehidupan dan lingkungan siswa. Benda atau bahan manipulatif adalah bahan-bahan yang dapat dipegang, dipindah-pindah, dipasang, dibolak-balik, diatur/ditata, dilipat/dipotong dan dapat dimain-mainkan oleh siswa.

Memang tidak mudah membawa para siswa mampu memahami konsep dan makna pecahan sehingga diperlukan suatu perubahan cara mengajar yang dilakukan oleh guru yang dikarenakan mungkin pengetahuan yang masih terbatas sehingga guru selalu menggunakan cara yang sama dari waktu. Untuk mengantisipasi masalah ini maka perlu dicarikan suatu formula pembelajaran yang tepat sehingga dapat meningkatkan kemampuan menyelesaikan masalah matematika khususnya pada pecahan. Para guru hendaknya terus berusaha menyusun dan menerapkan berbagai cara variansi agar siswa tertarik dan bersemangat dalam mengikuti pelajaran matematika salah satunya melalui metode penemuan terbimbing.

Perdata (2002) menyatakan bahwa penemuan terbimbing adalah suatu metode dalam kegiatan belajar mengajar yang melibatkan siswa secara aktif untuk menemukan pengetahuan baru berdasarkan pengetahuan yang telah dimilikinya di bawah bimbingan orang lain atau guru. Pada penemuan terbimbing, guru membimbing siswa agar melalui jalur yang benar dan menghindari usaha yang salah, memberikan pertanyaan yang dapat membantu siswa, dan mengenalkan ide kunci jika diperlukan.

Beberapa penelitian telah membuktikan bahwa penerapan metode penemuan terbimbing memberikan dampak yang positif tentang pembelajaran matematika. Jafaruddin (2005), mengatakan pembelajaran melalui penemuan terbimbing dapat membangun pemahaman siswa pada materi fungsi invers, di samping itu juga dapat melatih siswa untuk belajar secara aktif, mandiri, berpikir kritis dan kreatif, meningkatkan rasa percaya diri yaitu siswa lebih berani mengemukakan pendapat atau menjawab pertanyaan guru, kemudian dikatakan respon siswa terhadap model pembelajaran penemuan terbimbing pada materi invers sangat positif. Selanjutnya Al'ayubi (2005), mengatakan bahwa pembelajaran dengan metode penemuan terbimbing dapat memahamkan siswa pada materi luas persegi panjang, kemudian dikatakan bahwa siswa menyatakan senang mengikuti pembelajaran dengan metode penemuan terbimbing karena dapat menemukan sendiri rumus luas persegi panjang, dapat bekerja sama dalam kelompok dan dapat memanipulasi benda konkret.

Berdasarkan latar belakang di atas, maka yang menjadi rumusan masalah dalam penelitian ini adalah bagaimanakah meminimalkan kesalahan konsep pecahan melalui pembelajaran penemuan terbimbing dengan gesture produktif pada siswa SMP?.

\section{KAJIAN TEORI}

\section{Pentingnya Penemuan terbimbing}

Pembelajaran dengan penemuan adalah kegiatan pembelajaran yang sengaja dirancang dengan menggunakan pendekatan penemuan. Para siswa diajak atau didorong untuk melakukan kegiatan sedemikian sehingga pada akhirnya diharapkan siswa menemukan sesuatu yang diharapkan. Bruner (dalam Dahar, 1988:125) menyatakan bahwa penemuan sesuai dengan pencarian pengetahuan secara aktif oleh siswa, dan dengan sendirinya memberikan hasil yang paling baik. Berusaha sendiri untuk mencari pemecahan masalah serta pengetahuan yang menyertainya, sehingga menghasilkan pengetahuan benar-benar bermakna.

Metode penemuan merupakan komponen dari praktik pendidikan yang meliputi metode mengajar yang memajukan cara belajar aktif, berorientasi pada proses, mengarahkan sendiri, mencari sendiri dan reflektif. Menurut Encyclopedia of Educational Research, penemuan merupakan suatu strategi yang unik dapat diberi bentuk oleh guru dalam berbagai cara, termasuk mengajarkan keterampilan menyelidiki dan memecahkan masalah sebagai alat bagi siswa untuk mencapai tujuan pendidikannya. Dengan demikian dapat dikatakan bahwa penemuan adalah suatu metode dimana dalam proses belajar mengajar guru memperkenankan siswa-siswanya menemukan sendiri informasi yang secara tradisional biasa diberitahukan atau diceramahkan saja. 


\section{Pentingnya Gesture}

Gesture (sikap) merupakan salah satu sumber daya vital bagi siswa dalam berkomunikasi matematika. Gagasan kognisi diwujudkan memegang pengetahuan yang dibangun melalui pengalaman tubuh dengan lingkungan (Edwards, 2009). Dengan demikian, melakukan sesuatu, berpikir, mengajar, dan belajar tentang matematika melibatkan semiotic bundle (Arzarello, Paola, Robufti, \& Sabena, 2009) kata-kata, tanda-tanda, isyarat, artefak, dan representasi visual, yang dilalui pikiran, tubuh, dan dunia menjadi terintegrasi. Pada dasarnya, pembangunan makna matematika atau semiotic dianggap proses multimodal, yang melibatkan interaksi antara beberapa modalitas penglihatan, pendengaran, sentuhan, dan tindakan motorik.

McNeill (1992) mengklasifikasikan gerakan dalam kategori yang berbeda: deicti Gesture (Menunjuk ke obyek yang sudah ada atau virtual), metaforis Gesture (Representasional), iconic gesture (hubungan kemiripan dengan isi semantik berbicara), beat gesture (sederhana diulang gerakan yang digunakan untuk penekanan). Banyak peneliti telah menganalisis bagaimana gesture dan bahasa komunikasi bekerja sama dan saling mempengaruhi.

Gesture menunjuk ditandai dengan menggunakan jari-jari, tangan, atau kadang-kadang alat tulis, untuk spesik benda fisik, tempat, atau orang, atau untuk menunjukkan unsur-unsur dalam ruang gestural dimaksud dalam ucapan tetapi tidak hadir secara visual (McNeill, 1992). Secara khusus, McNeill melihat gesture menunjuk dibuat dalam referensi, artefak dan representasi visual yang berkaitan dengan tugas-tugas (misalnya: lembar kerja, whiteboar (manipulatif). Tindakan menunjuk berfungsi sebagai kegiatan interaktif yang dapat mengatur peserta, percapakan terjadi secara bersama, dan benda-benda yang ditunjukkan (Goodwin, 2003). Dengan demikian, sikap menunjuk memainkan peran penting dalam dasar ucapan sikap tubuh maupun lisan. Sebagai contoh, gesture menunjuk.

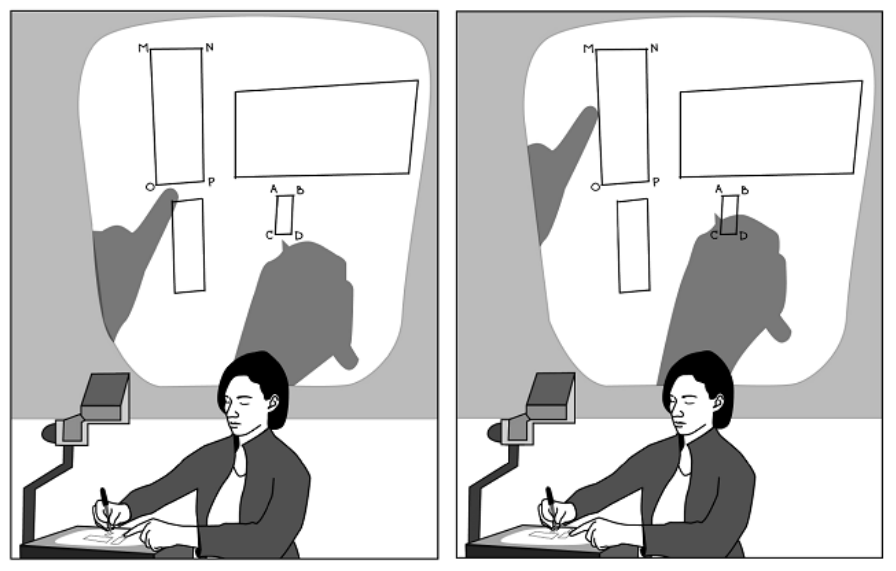

Gambar 1. Gesture Menunjuk

Gambar di atas mengilustrasikan keduanya menggunakan gesture guru yang sama dengan ucapan siswa saat ia menyuarakan ulang bahwa ucapan dan gesture guru dari serangkaian gesture menunjuk menyorot hubungan antara representasi. kutipan ini adalah bagian dari peristiwa di mana guru menyoroti hubungan antara dua persegi panjang yang sama. Seperti yang terlihat pada Gambar diatas, guru memproyeksikan beberapa bentuk dari persegi panjang melalui overhead projector. Dia meminta seorang mahasiswa untuk membenarkan mengapa dua bentuk tersebut serupa. Perhatikan juga bahwa untuk setiap pasang sisi yang sesuai, guru menggunakan gerak tubuh (gesture) yang berurutan, tetapi dalam setiap kasus ia memegang titik pertama ke sisi atas persegi panjang yang lebih kecil sementara ia menunjuk ke sisi yang sesuai pada persegi panjang yang lebih besar. Dengan demikian, kedua item ini terkait secara bersamaan. 
Gesture Representational (yaitu iconic dan metaphor) sangat penting untuk merepresentasikan informasi non-verbal untuk akhirnya ditempatkan sebagai informasi verbal. Secara khusus, representational gesture mungkin merupakan cerminan bagaimana konsep pemecah masalah tertentu (Chu \& Kita, 2008, dalam Kirsten J. Muser, 2010). Gesture tersebut akan menunjukkan bagaimana dan dimana menempatkan dengan benar bagian-bagian artefak secara selektif digunakan selama deictic gesture, dan membawa konten semantik yang mewakili atribut, gerakan, dan hubungan antara objek.

Representational gesture akan memberikan informasi tentang petunjuk/wawasan pengetahuan untuk memahami bagaimana memperoleh konsep solusi untuk memecahkan masalah tertentu, dan dapat berfungsi sebagai bantuan dalam mengatasi kesulitan yang mungkin dialami siswa selama proses pembelajaran berlangsung.

Gesture metaphor menggambarkan makna melalui perumpamaan (misalnya, menangkupkan tangan seolah-olah "memegang", ide yang mencerminkan metafora adalah benda). McNeill (1992) menyajikan bukti bahwa konseptual metafora sering diwujudkan dalam gesture representational yang menggambarkan konsep-konsep abstrak dalam hal gambar. metafora ini sering diwujudkan dalam gesture yang menggambarkan memegang atau mentransfer benda. Sebagai contoh, seorang pembicara akan memperpanjang tangannya seolah memegang sesuatu sambil berkata, "saya punya ide bagus"

\section{Mengenal Konsep Pecahan}

Kegiatan mengenal konsep pecahan akan lebih berarti denga di dahului dengan soal cerita yang menggunakan obyek buah, misalnya apel, sawo, jeruk atau kue misal apem dll. Peraga selanjutnya berupa bangun datar seperti persegi, lingkaran yang nantinya akan sangat menbantu dalam pemahaman konsep.

Pecahan $\frac{1}{2}$ dapat di peragakan dengan melipat kertas berbentuk lingkaran atau persegi sehingga lipatannya tepat menutupi bagian yang lainya. Selanjutnya bagian yang dilipat dibuka dan diarsir sesuai bagian yang di kehendaki, sehingga didapat gambar sebagai berikut:
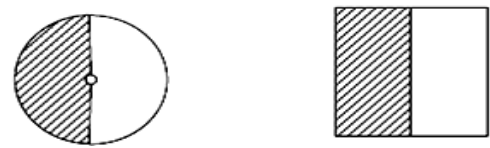

Pecahan $\frac{1}{2}$ dibaca setengah atau satu per dua atau seperdua. "1" disebut pembilang yaitu merupakan daerah pengambilan. " 2 " disebut penyebut yaitu merupakan 2 bagian yanga sama dari keseluruhan.

Peragaan tersebut dapat dilanjutkan untuk pecahan $\frac{1}{4}$ an, $\frac{1}{8}$ an dan sebagainya. Gambarnya sebagai berikut:
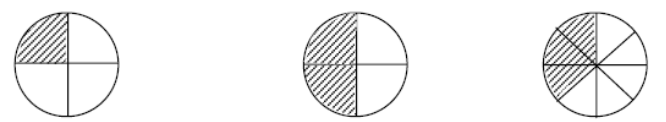

$\mathrm{Gb} .1=\frac{1}{4} \quad$ gb. $2=\frac{2}{4} \operatorname{atau} \frac{1}{2} \quad$ gb. $3=\frac{3}{8}$

Selain mengenalkan pecahan dengan melipat kertas, peragaan dapat pula di lakukan denga pita atau tongkat yang di potong dengan pendekatan pengukuran panjang, yang dapat pula mengenalkan letak pecahan pada garis bilangan 


\section{METODE PENELITIAN}

Penelitian ini bertujuan mendeskripsikan proses meminimalkan kesalahan konsep pecahan melalui pembelajaran penemuan terbimbing dengan gesture produktif pada siswa SMP. Pengambilan datanya dilakukan secara verbal, sehingga penelitian ini tergolong penelitian kualitatif.

Instrumen utama pada penelitian ini adalah peneliti sendiri, karena peneliti yang merencanakan, merancang, melaksanakan, mengumpulkan data, menganalisis data, menarik kesimpulan dan membuat laporan. Untuk memperkuat data dalam penelitian ini, maka diperlukan instrumen penunjang. Instrumen penjunjang yang dimaksud adalah alat yang digunakan untuk mengumpulkan data tentang penemuan terbimbing dengan gesture produktif pada siswa SMP pada konsep pecahan, yaitu:

1. Rencana Pelaksanaan Pembelajaran

Agar pembelajaran penemuan terbimbing dapat dilaksanakan dengan efektif dan efisien serta dapat mencapai tujuan yang ingin dicapai maka perlu rencana pelaksanaan pembelajaran. Dalam rencana pelaksanaan pembelajaran memuat tiga tahapan pembelajaran yaitu, yaitu tahap pendahuluan meliputi mengingatkan kembali konsep bilangan bulat, dan menyampaikan tujuan pembelajaran. Tahap inti meliputi mengamati bentuk manipulasi objek, membuat hipotesis, menjelaskan dan membuat kesimpulan. Sedangkan tahap penutup meliputi evaluasi.

2. Lembar Tugas

Lembar tugas yang digunakan dalam penelitian ini berupa masalah pecahan yang digunakan untuk mengetahui sejauh mana keberhasilan dalam meminimalisasi kesalahan konsep pecahan.

\section{Prosedur Penelitian}

Para peserta diwawancarai secara berpasangan oleh peneliti dalam sesi yang berlangsung sekitar 30 menit. Sesi ini direkam, dan dimulai dengan sipewawancara meminta masing-masing peserta merancang sejumlah pertanyaan untuk menggali ingatan mereka tentang pecahan dan caracara mereka berbicara dan berpikir tentang topik pecahan. Selain itu siswa kemudian diminta untuk menyelesaikan lima masalah secara tertulis, masing-masing pada selembar kertas yang terpisah, yang terdiri dari perbandingan sederhana, penambahan, pengurangan, perkalian dan pembagian pecahan dan bilangan campuran. Mereka bersama-sama bekerja pada masalah, dan kemudian diminta untuk menjelaskan solusi mereka. Berikut kerangkan prosedur penelitian.

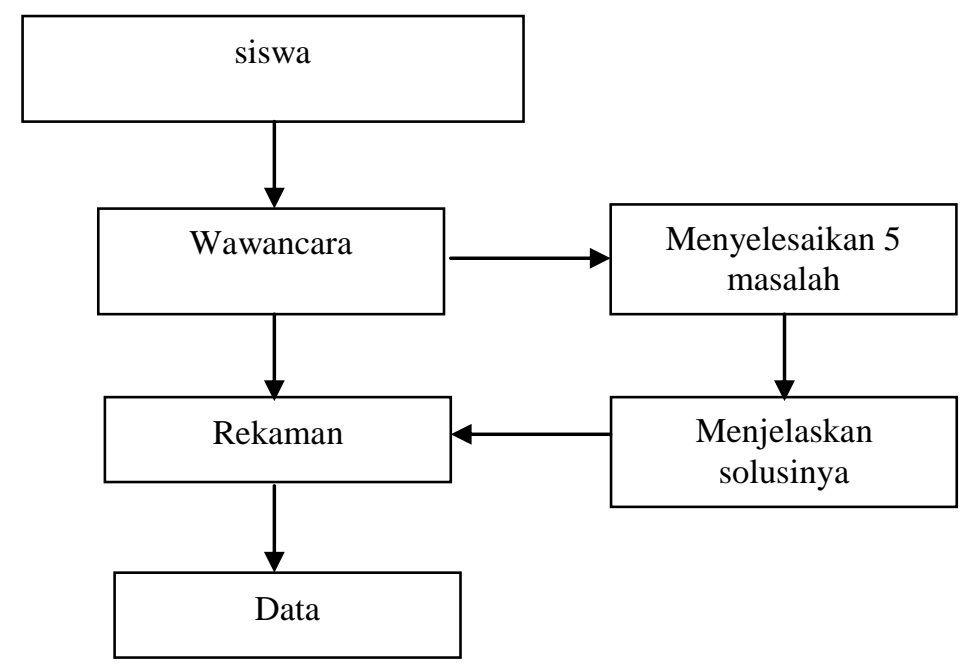

Gambar 2. Prosedur Penelitian 


\section{PEMBAHASAN}

\section{Hasil Investigasi}

Berdasarkan hasil pengamatan maka dapat disimpulkan sebagai berikut:

- Aktivitas belajar siswa hanya terjadi satu arah antara guru dengan siswa, tidak adanya kesempatan yang diberikan oleh guru melakukan interaksi antar siswa sehingga dalam pembelajaran seharusnya siswa diberikan kesempatan untuk lebih banyak melakukan aktivitas melalui diskusi kelompok dan interaksi anata siswa.

- Tidak adanya perangkat pembelajaran yang digunakan oleh guru dalam melakaukan proses pembelajaran sehingga dalam penelitian ini perlu disusun desain pembelajaran yang mampu merangsang aktivitas siswa, sehingga lebih efektif dalam menanamkan konsep yang diajarkan.

- Dalam pembelajaran di kelas, siswa menggunakan lembar kerja siswa yang di perjualbelikan oleh penerbit sehingga dalam penelitian ini disusun perangkat pembelajaran yang lain berupa lembar tugas yang telah disesuaikan dengan kemampuan siswa.

\section{Pengambilan Data I}

Pada pertemuan pertama, guru mengawali dengan berdoa dan meminta siswa untuk mengeluarkan catatan matematika. Selain itu, guru meminta siswa untuk mengorganisasikan menjadi 8 kelompok dan sekaligus setiap anggota pada kelompoknya telah memiliki lembar tugas (LT) yang telah disiapkan oleh peneliti.

Selanjutnya guru, memberikan standar kompetensinya dengan membacakan standar kompetensi yang harus dicapai, lalu menyampaikan topik yang akan dipelajari. Kegiatan pembelajaran dilanjutkan dengan eksplorasi untuk menggali pengetahuan awal siswa melalui pertanyaan "ada berapa bagian pada buah jeruk ini?" Siswa merespon dengan jawaban sama, sepertiga bagian, peneliti memberi pujian bagus.

Dalam menjalankan strategi membuat konjektur, guru menjalankan fungsinya sebagai fasilitator untuk memberikan bantuan secukupnya pada siswa dengan cara berkeliling setiap kelompok diskusi. Bantuan ini berupa pertanyaan untuk membantu siswa memahami suatu materi (prompting) dan pertanyaan untuk mengetahui tingkat pemahaman siswa (probing). Peneliti juga berusaha mengaktifkan siswa pada semua kelompok dengan menanyakan pendapat mereka tentang tugas yang diberikan dalam lembar tugas (LT).

Dari hasil pengamatan peneliti hampir semua kelompok tidak mengalami kesulitan dalam menyelesaikan langkah 1 sampai langkah 5. Ketika guru berkeliling didapati hasil kerja kelompok 2 melakukan perhitungan yang kurang tepat. Kemudian guru memberikan bimbingan secara klasikal pada contoh yang lain $\left(\frac{1}{4}+\frac{1}{2}\right)$ dengan meminta siswa terlebih dahulu menggambarkan seperempat dan seperdua. Selanjutnya menghitung bagian yang diarsir dari seperempat dan seperdua. Protocol antara guru dan kelompok 2 sebagai berikut:

Guru: "Coba seperempat dan seperdua jika direpresentasikan kedalam gambar seperti apa?

Siswa: Menggambar "Begini gambarnya ibu?"

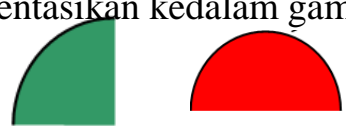

Guru: "Sekarang masing-masing arsiran dikumpulkan, daerah yang diarsir menjadi berapa bagian?"

Siswa: "Sambil berdiskusi dengan temannya "ini seperempat dan ini seperdua selanjutnya jika digabung akan menjadi begitu bu?"

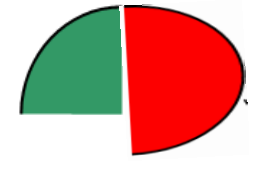


Guru: "Terus gambar dari seperdua itu bias dirubah menjadi gambar dua perempat"

Siswa: Berdiam sebentar "Oh iya bu, saya sudah mengerti sekarang. Jadi kalau digambar seperempat dengan seperdua ini menjadi tiga perempat"' Jadi dapat disimpulkan bahwa $\frac{1}{4}+\frac{1}{2}=\frac{3}{4}$

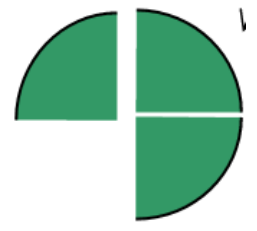

Setelah berjalan 40 menit kegiatan diskusi kelompok segera diakhiri dan dilanjutkan dengan presentasi dari masing-masing kelompok sedangkan kelompok lain menanggapi dengan mengajukan pertanyaan jika kurang jelas dari pembahasan kelompok tersebut. Masing-masing kelompok diberi waktu 5 menit untuk mempresentasikan hasil diskusi kelompoknya.

Dari diskusi pada pertemuan pertama tersebut diperoleh hasil sebagai berikut:

a. Penjumlahan atau pengurangan dua pecahan mempunyai penyebut sama dapat dilakukan dengan menjumlahkan atau mengurangi pembilang dari kedua pecahan tersebut, sedangkan penyebutnya tetap.

b. Penjumlahan atau pengurangan dua pecahan mempunyai penyebut tidak sama dan salah satu penyebutnya merupakan kelipatan penyebut yang lain, dapat dilakukan dengan menyamakan penyebutnya terlebih dahulu kemudian baru dijumlahkan atau dikurangi.

\section{Pengambilan Data II}

Pada pertemuan kedua, dilaksanakan pada hari Jumat, 13 September 2013. Tujuan pembelajaran pada pertemuan kedua adalah kemampuan dan pemahaman siswa dalam mengalikan dan membagi pecahan baik dalam bentuk penyebut yang sama maupun berbeda yang dilanjutkan dengan penyelesaian masalah dalam kehidupan sehari-hari terkait dengan perkalian dan pembagian pecahan.

Peneliti memulai pembelajaran dengan salam dan menanyakan kesiapan siswa untuk menerima pembelajaran. Pada pertemuan ini siswa tampaknya lebih siap dibandingkan dengan pertemuan pertama karena sudah memahami situasi kegiatan pembelajaran yang diterapkan oleh guru. Guru berusaha memberi motivasi kepada siswa agar tetap bersemangat mengikuti pembelajaran. Dan menanyakan tugas yang diberikan pada pertemuan kemarin apakah ada kesulitan, ternyata seluruh siswa tidak mengalami kesulitan mengerjakan tugas tersebut dan setelah dicek semuanya menjawab dengan benar.

Pada tahap ini strategi penguatan dijalankan dengan mengingatkan kembali tentang materi sebelumnya dengan memberikan pertanyaan sebagai berikut:

Guru: 'Dapatkah kalian mencari Berapa meter pita yang diperlukan bila ada 3 siswa, jika setiap siswa memerlukan $\frac{1}{5}$ meter pita untuk membuat kerajinan bunga?

Siswa 1: "Dapat Pak, $\frac{1}{5}+\frac{1}{5}+\frac{1}{5}=\frac{3}{5}$ ?"

Guru: "Apakah ada yang mempunyai pendapat lain? Dan bagaimanakah kemungkinan alternatif penyelesaian?"

Kemudian guru membagi lembar tugas (LT) dan menjelaskan kompetensi dasar dan tujuan pembelajaran yang ingin dicapai. Pada pertemuan hari ini tujuan pembelajaran yang ingin dicapai adalah siswa dapat memahami perkalian dan pembagi pecahan serta penyelesaian masalah dalam kehidupan sehari-hari.

Selanjutnya, pada tahap inti guru menjelaskan sekali lagi kepada siswa agar lebih aktif dalam melaksanakan diskusi kelompok dan menyelesaikan tugas dengan tepat waktu. Pelaksanaan diskusi pada pertemuan hari ini selama 40 menit. Siswa bekerja secara berkelompok untuk menyelesaikan 
lembar tugas 2 yang telah diberikan dengan mengatur pembagian tugas pada setiap anggota kelompoknya agar tepat waktu dalam menyelesaikan tugas kelompok.

Pada tahap ini strategi-strategi memahami masalah dan pembuatan konjektur dilaksanakan melalui lembar tugas (LT) yang harus diselesaikan siswa. Strategi penyusunan konjektur dilaksanakan dengan memberikan kesempatan kepada siswa melakukan diskusi kelompok untuk menyelesaikan lembar kerja siswa yang diberikan. Pada pertemuan ini, terlihat ada peningkatan dalam pelaksanaan diskusi. Meskipun masih ada beberapa siswa yang masih pasif dalam kelompoknya, namun secara keseluruhan pelaksanaan diskusi hari ini lebih aktif dibandingkan dengan pelaksanaan diskusi pada pertemuan yang pertama. Siswa yang cenderung pasif mulai berani bertanya pada temannya dan menyatakan pendapatnya.

Guru: "coba sekarang perhatikan kalimat tersebut, apa bisa kita representasikan ke dalam gambar?

FM: Melihat masalah itu, "Bisa Bu?"

Guru: "Coba bagaimana bentuk representasi dari tiang dan bambu itu?"

FM: "Sambil menggambar bambu $14 \mathrm{~m}$

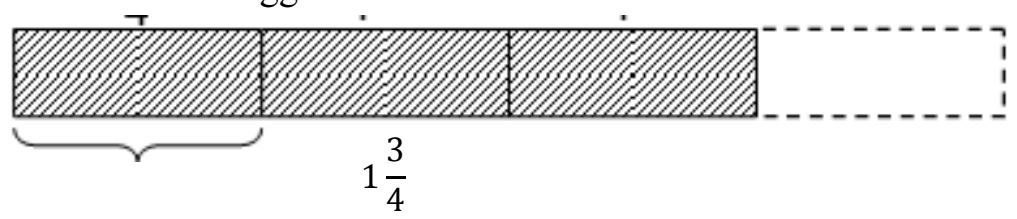

Guru: “Ok, selanjutnya sampai berapa banyak $1 \frac{3}{4}$ pada bamboo yang memiliki panjang 14 meter?"

FM: lalu siswa menghitung secara algoritma dengan melakukan variabel seperti " $1 \frac{3}{4} x A=14$ ?"

Guru: "Kenapa menjawab seperti itu?"

FM: sambil berpikir "Iya bu, maksud dari soal itu kan seberapa banyak $1 \frac{3}{4}$ sehingga mencapai 14 itu bu?"

Guru: "Ok, sekarang coba dilanjutkan perhitungannya?"

FM: "Karena $1 \frac{3}{4} x A=14$ maka $A=14: 1 \frac{3}{4}$ berdasarkan pengurangan berulang maka diperoleh $14-1 \frac{3}{4}-1 \frac{3}{4}-1 \frac{3}{4}-1 \frac{3}{4}-1 \frac{3}{4}-1 \frac{3}{4}-1 \frac{3}{4}-1 \frac{3}{4}=0$, sehingga diperoleh $1 \frac{3}{4}$ sebanyak 8 . Jadi banyaknya tiang sebanyak 8 "

Guru: "Ok, lanjutkan dengan tugas yang belum terselesaikan ya?"

Kegiatan selanjutnya adalah kegiatan presentasi hasil diskusi. Kelompok empat yang diwakili oleh FM membacakan hasil diskusi kelompoknya. Terlihat diskusi berjalan lebih baik lagi dari pertemuan pertama. Kemudian guru meminta kelompok yang lain untuk menanggapi jawaban hasil diskusi kelompok empat. Namun tidak ada sanggahan atas jawaban yang berikan oleh kelompok empat. Berdasarkan kegiatan diskusi yang telah dilakukan siswa, kemudian guru meminta siswa menyimpulkan tentang perkalian dan pembagian pecahan.

Dari diskusi pada pertemuan kedua tersebut diperoleh hasil sebagai berikut:

1. Bilangan asli dikalikan dengan pecahan hasilnya adalah bilangan asli itu dikalikan pembilangnya, sedangkan penyebutnya tetap, begitu juga sebaliknya.

2. Bilangan asli dikalikan dengan pecahan campuran hasilnya dapat diperoleh dengan mengubah terlebih dahulu bentuk pecahan campuran ke bentuk pecahan biasa, kemudian hasilnya adalah bilangan asli itu dikalikan pembilangnya, sedangkan penyebutnya tetap.

3. Pecahan campuran dikalikan pecahan campuran hasilnya dapat diperoleh dengan mengubah terlebih dahulu pecahan campuran ke bentuk pecahan biasa dan selanjutnya menggunakan kunci pembilang kali pembilang dan penyebut kali penyebut 


\section{Hasil Pembelajaran}

Analisis data pada penelitian ini mengenai prestasi belajar dan gesture pada saat dilakukan wawancara. Pada tes siswa yang diberikan meliputi: perbandingan sederhana, penambahan, pengurangan, perkalian dan pembagian pecahan dan bilangan campuran serta penyelesaian masalah dalam kehidupan sehari-hari.

Dari hasil tes belajar siswa yang berjumlah 23 siswa diperoleh data sebagai berikut:

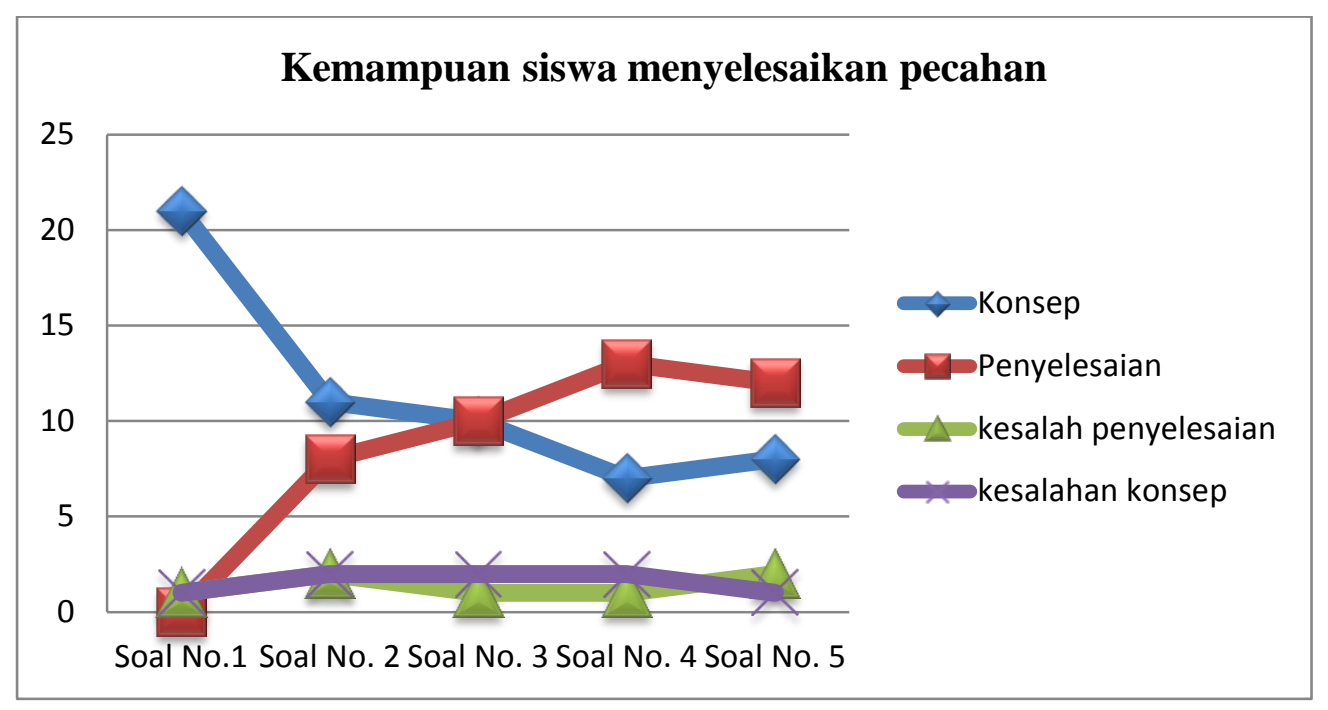

Gambar 3. Kemampuan Siswa Menyelesaikan Pecahan

Dari data diatas diperoleh bahwa kesalah siswa dalam konsep dan penyelesaian masalah $13 \%$, ini artinya kesalahan yang dilakukan oleh siswa pada saat belajar operasi pecahan dan penyelesaian masalah dapat diminimalkan dengan pembelajaran penemuan terbimbing. Pembelajaran penemuan terbimbing, yang dikaji dalam penelitian ini adalah menyajikan informasi dengan mengamati bentuk manipulasi objek, membuat konjektur, menjelaskan, dan mengevaluasi. Berikut langkah-langkah pembelajaran penemuan terbimbing.

Tabel 1. Langkah-langkah Pembelajaran Penemuan Terbimbing

\begin{tabular}{|l|r|l|}
\hline \multicolumn{1}{|c|}{ TAHAP } & PERAN GURU \\
\hline Mengamati Bentuk & 1. & $\begin{array}{l}\text { Guru menyampaikan masalah yang dapat } \\
\text { mengarahkan siswa untuk dapat memecahkan } \\
\text { masalah pecahan dengan jalan tanya jawab atau lewat } \\
\text { lembar tugas (LT). }\end{array}$ \\
2. & $\begin{array}{l}\text { Guru memberikan informasi untuk } \\
\text { menginterpretasikan masalah menjadi bentuk konkrit } \\
\text { dengan meminta siswa terlebih dulu memahami } \\
\text { masalah pecahan. }\end{array}$ \\
\hline Membuat konjektur & 1. $\begin{array}{l}\text { Guru memberikan kesempatan kepada siswa untuk } \\
\text { memprediksi/menduga berbagai solusi atas unsur } \\
\text { yang diketahui. }\end{array}$ \\
& 2. $\begin{array}{l}\text { Guru meminta siswa untuk mendiskusikan dengan } \\
\text { anggotanya mengenai prediksi/dugaan } \\
\text { penyelesaiannya. } \\
\text { Guru membantu siswa mencari strategi dalam } \\
\text { menjawab masalah pecahan. }\end{array}$ \\
\hline Menjelaskan & 1. $\begin{array}{l}\text { Guru mengevaluasi hasil belajar tentang pecahan } \\
\text { dengan cara mempresentasikan hasil kerjanya. } \\
\text { Guru memberikan kesempatan kepada siswa untuk } \\
\text { menjelaskan secara tulis dan lisan mengenai hasil }\end{array}$ \\
\hline 2.
\end{tabular}




\begin{tabular}{|l|l|}
\hline & 3. $\begin{array}{l}\text { kerjanya (berbekal penyelesaian yang telah diyakini } \\
\text { secara kelompok). } \\
\text { Guru memberikan kesempatan kepada siswa untuk } \\
\text { melakukan tanya jawab (pertanyaan, masukan- } \\
\text { masukan atau tanggapan) mengenai penjelasan hasil } \\
\text { pekerjaan siswa. }\end{array}$ \\
\hline Menyimpulkan & 1. $\begin{array}{l}\text { Guru memberi kesempatan kepada siswa untuk } \\
\text { menentukan kesepakatan penyelesaian dengan } \\
\text { kelompoknya. }\end{array}$ \\
2. $\begin{array}{l}\text { Guru bersama siswa membuat kesimpulan tentang } \\
\text { masalah pecahan. }\end{array}$ \\
\hline
\end{tabular}

\section{Gesture dan Konsep Pecahan}

Selain mengkaji tentang pemahaman siswa dari hasil kerjanya, pada penelitian ini juga melibatkan gesture siswa, dengan kata lain peneliti mencoba menggali pemahaman berdasarkan wawancara ke siswa yang komunikatif. Pengambilan siswa ini berdasarkan pada sifat komunikatif dari siswa.

Dalam penelitian ini, para partisipan berbicara tentang pecahan sebagai bagian dari keseluruhan, tetapi juga sebagai simbol yang dapat dimanipulasi atau dioperasikan. Mereka juga sering digambarkan penggunaan benda nyata, yaitu matematika manipulatif dan realia, dalam mempelajari tentang pecahan (12\% dari geture sekitar obyek tersebut).

Konsep pecahan dapat didefinisikan dalam beberapa cara, tergantung pada konteks dan siswa. Definisi dasar dari suatu pecahan $\frac{m}{n}$ dari objek merupakan jumlah yang diperoleh dengan membagi objek ke bagian $n$ yang sama dan mengambil $m$ dari bagiannya. (Jensen, 2003.). Pecahan juga didefinisikan sebagai pernyataan hasil bagi dari dua kuantitas. Dari pandangan yang berbeda, pecahan dianggap hanya sebagi notasi, angka, symbol dan dua angka yang ditulis dengan palang diantara angka-angka (Lamon, 1999).

Dalam penelitian ini, para siswa berbicara tentang pecahan sebagai bagian dari keseluruhan, tetapi juga sebagai simbol yang dapat dimanipulasi atau dioperasikan. Mereka juga sering digambarkan penggunaan benda nyata, yaitu matematika manipulatif dan realia, dalam mempelajari tentang pecahan (12\% dari geture sekitar obyek). Berikut hasil analisis gesture produktif yang dibangun oleh siswa terhadap pecahan.

\section{Pecahan sebagai bagian dari keseluruhan}

Mengacu definisi dasar pecahan, yaitu membagi keseluruhan menjadi potongan-potongan dengan ukuran yang sama. Siswa menyatakan gagasannya tentang pecahan, gesture ini merujuk pada "pemotongan, pembelahan, dan mengiris" yang seringkali di ucapkan oleh siswa. Berikut petikan wawancara peneliti dengan Fatimah $(\mathrm{Fa})$

Peneliti: "Fat, apa kamu mengenal dan tau dengan pecahan?"

Fatimah: ..hemm "Iya Pak, kenapa ya pak"

Peneliti: "pecahan itu menurutmu apa Fat?"

Fatimah: ...."Apa ya pak?" termenung.."setengah itu pecahan, lima pertiga pecahan, tapi apa ya pecahan?"

Peneliti: "coba kamu kaitkan pecahan dengan roti, misalnya?"

Fatimah: hemmm.. (terdiam) "iya misalkan ada kue utuh, lalu saya potong kuenya dengan bagian yang sama gitu pak?"

Peneliti: "lalu, bagaimana?"

Fatimah: "iya begitu pak, pecahan seperti itu, jika kue utuh saya potong dalam bagian yang sama maka itu pecahan pak? 
Peneliti: “maksudmu, apa Fat?"

Fatimah: "pecahan yang saya maksud itu, potongan-potongan kue dari kue yang utuh itu pak?"

Berdasarkan hasil wawancara peneliti dengan Fatimah, bahwa pengetahuan Fatimah terhadap pecahan tidak bias dilakukan secara formal. Akibatnya, peneliti mencoba memberikan bantuan (scaffold) dalam pertanyaan "coba kamu kaitkan dengan kue, misalnya?". Dari pertanyaan peneliti, Fatimah mencoba mengaitkan pecahan dengan kue, sehingga secara tidak langsung Fatimah memberikan pengertian bahwa pecahan selalu odentik dengan potongan-potongan kue. selalu disamakan dengan potongan-potongan kue.

Berdasrkan analisis yang dilakukan oleh peneliti terhadap pemahaman Fatimah pada pecahan, terjadi pula kepada Irwan yang berpikir bahwa pecahan merupakan potongan-potongan dari sesuatu yang utuh. Terdapat 3 gesture produktif dari seluruh gerakan yang mengatakan bahwa pecahan itu potongan-potongan. Salah satu contoh sikap yang ditunjukkan oleh irwan, dimana irwan menjelaskan pecahan dengan meotong secara melintang dan harus dalam bagian yang sama.

\section{Gesture secara numerik}

Dari 2 siswa pada sesi wawancara terhadap pemahaman pecahan, secara total ada 15 gesture produktif. Kumpulan ini sudah termasuk gesture deictics (menunjuk pada kertas) yang terjadi pada saat peneliti melakukan wawancara terhadap hasil kerjanya. Tingkatan siswa untuk menunjukkan gesture tidak terlalu banyak dilakukan, karena siswa usia 13-14 tidak banyak memproduksi gesture ketika dilakukan wawancara. Justru, siswa lebih senang mengerjakan soal dibandingkan diwawancarai seberapa besar pemahaman siswa. Berdasarkan analsis peneliti, dari 15 gesture itu yang banyak muncul pada gesture deictics. Berikut secara numerik gesture yang dibangun oleh siswa.

\begin{tabular}{lccccc}
\hline & Iconic & Beat & Methapor & Deictics & Lain \\
\hline Banyaknya & 5 & 3 & - & 7 & - \\
\hline
\end{tabular}

McNeill mengembangkan dimensi-dimensi dari cospus 790 gesture yang dikumpulkan dari partisipan yang diminta untuk menonton kartun animasi dan kemudian menggambarkannya. Diharapkan bahwa wawancara tentang matematika akan menimbulkan gesture iconic yang lebih sedikit dan methaporic lebih banyak daripada di corpus McNeill 's, dan harapan ini dikuatkan: dalam narasi "kartun", $41 \%$ dari geture itu terutama ikonik dan hanya $2 \%$ metaphor, dibandingkan dengan 23\% dan 26\%, masing-masing, untuk wawancara pecahan (McNeill, 2005:42).

\section{PENUTUP}

Kesimpulan dalam pembelajaran penemuan terbimbing terhadap meminimalkan kesalahan pecahan terdiri dari mengamati bentuk manipulasi objek, membuat konjektur, menjelaskan, dan mengevaluasi. Indikator ini bisa dimodifikasi sesuai dengan materi pelajaran matematika pada SMP. Selain penelitian ini hanya pada hasil kerja siswa, maka dilihat juga gesture yang dibagun oleh siswa.

Gesture yang dibagun oleh siswa untuk mendefinisikan pecahan ternyata perlu adanya benda nyata (seperti kue). Namun, karena konsep-konsep yang belum dipahami oleh anak-anak, sulit untuk melihat bagaimana bisa dirancang dengan cermat untuk "mewakili" atau "menyampaikan" ide-ide. Gagasan manipulatif sebagai pembawa berita terhadap materi yang lebih produktif, dan scaffold (hubungan bimbingan guru) masih diperlukan untuk mempertajam pemahaman siswa terhadap pecahan. Sebagian siswa menghasilkan gesture ditimbulkan dari tangan manipulative atau realita, dan banyak gesture yang belum muncul saat mereka berhubungan dengan pemahaman pecahan.

Gerakan ini, sekali lagi, bukti bagaimana siswa berpikir tentang pecahan, begitu ia/dia telah belajar bagaimana untuk memanipulasi pecahan secara simbolis. Secara umum, guru berpikir hanya bisa meningkatkan "pemahaman siswanya" dengan memperhatikan modalitas dari gesture, dan 
mempertimbangkan sumber dari gesture ini dengan cermat dan pemetaan konseptual yang dapat memproduksi mereka. Oleh karena itu, saran dalam penelitian ini perlu penelitian khusus terkait dengan geture produktif yang dibangun oleh siswa..

\section{DAFTAR RUJUKAN}

Alibali, M. W., Kita, S., \& Young, A. 2000. Gesture and the Process of Speech Production: We think, Therefore we Gesture. Language and Cognitive Processes, 15, 593-613.

Arzarello, F. 2006. Semiosis as a Multimodal Process. Revista Latinoamericana de Investigacion en Matemática Educativa, Numero Especial, 267-299.

Behr, M. J., Harel, G., Post, T., \& Lesh, R. 1992. Rational Number, Ratio, and Proportion. In D. A. Grouws (Ed.) Handbook of Research on Mathematics Teaching and Learning (pp. 296 -333). New York:Macmillan.

Edward, L. 2009. Gestures and Conceptual Integration in Mathematical Talk. Educational Studies in Mathematics Volume 70, Issue 2, pp 127-141. Springer Netherlands

Goldin-Meadow, S. 2003. Hearing Gestures: How our Hands Help us Think. Chicago: University of Chicago Press.

Mack, N. K. 1990. Learning Fractions with Understanding: Building on Informal Knowledge. Journal for Research in Mathematics Education, 21(1), 16-32.

McNeill, D. 1992. Hand and Mind: What Gestures Reveal about Thought. Chicago: University of Chicago Press.

McNeill, D. (Ed.). 2000. Language and Gesture. Cambridge: Cambridge University Press.

Muhsetyo, Gatot,dkk. 2007. Pembelajaran Matematika SD. Jakarta: Universitas Terbuka

Sobel, M.A. \& Maletsky, E.M.. 1975. Teching Mathematics: A. Sourcebook of Aids, Activities, and Strategies. New Jersey: Prentice-Hall.

Sucipto. 2009. Meminimalkan Miskonsepsi Operasi Pecahan melalui Metode Pembelajaran Teknik Discovery Siswa Kelas V SDN Purwantoro 5 Malang. Penelitian tidak dipublikasikan: Universitas Wisnuwardhana Malang. 